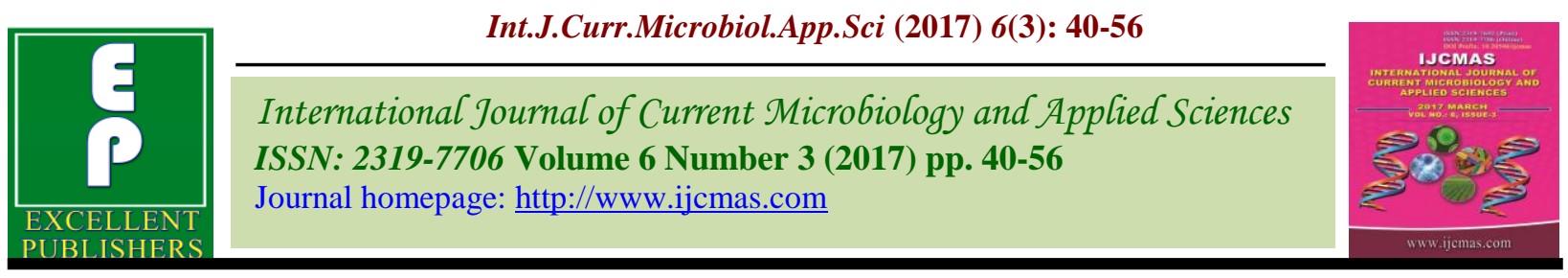

Original Research Article

https://doi.org/10.20546/ijcmas.2017.603.004

\title{
Vulnerability Assessment of Soil Erosion/Deposition in a Himalayan Watershed using a Remote Sensing and GIS Based Sediment Yield Model
}

\author{
S.S. Rawat ${ }^{1}$, M.K. Jain ${ }^{2}$, K.S. Rawat ${ }^{3}$, B. Nikam ${ }^{4}$ and S.K. Mishra ${ }^{5}$ \\ ${ }^{1}$ National Institute of Hydrology, Roorkee-247 667, Uttarakhand, India \\ ${ }^{2}$ Department of Hydrology, Indian Institute of Technology-Roorkee, Roorkee-247 667, \\ Uttarakhand, India \\ ${ }^{3}$ Center for Remote Sensing and Geo-Informatics, Sathyabhama University, \\ Chennai-600 119, India \\ ${ }^{4}$ Indian Institute of Remote Sensing, ISRO, Dehradun-248 001, Uttarakahnd, India \\ ${ }^{5}$ Department of Water Resources Development and Management, Indian Institute of \\ Technology-Roorkee, Roorkee-247 667, Uttarakhand, India \\ *Corresponding author
}

\section{A B S T R A C T}

Soil erosion strongly affects crop yield, undermines the long term productivity of farm land and sustainability of farming system, and poses a major threat to the livelihood of the farmers and rural communities. The United Nations Environmental Program reported that the productivity of soil has reduced and resulting in economically unfeasible cultivation on

Keywords about 20 million hectare of land each year due to soil erosion and resulting degradation of land. The eroded soil is also a major cause of loss of storage capacity (1 to $2 \%$ annual reduction globally) of multipurpose reservoirs due to sedimentation which affects society

GIS, RS, Soil erosion, Sediment yield, USLE, Transport capacity.

Article Info

Accepted:

08 February 2017

Available Online:

10 March 2017 at large. In developing countries like India, limited data availability constrains the application of the sophisticated models in proper planning of erosion control measures. In the present study, a simple spatially distributed model has been formulated in GIS environment for mapping areas vulnerable to soil erosion and deposition in a Himalayan watershed from India. The model discretizes the spatial domain of catchment into homogenous grids/cells to capture the catchment heterogeneity and derived net erosion and deposition maps by considering gross soil erosion and transport capacity of each cell. Spatial distribution capability of the model has been checked at outlet as well as three upstream gauging sites using eight years historical sediment yield data. The model estimated the seasonal sediment yield with less than $\pm 30 \%$ errors. Finally, entire watershed has been classified into six different severity scales of erosion i.e. slight, moderate, high, very high, severe and very sever. Such maps have immense significance to prioritize area specific watershed conservation and management measures.

\section{Introduction}

Soil erosion is a serious problem in Himalayas and foothill ecosystem. Eighty percent of the sediment material delivered to the world's oceans each year comes from
Asian rivers, and amongst these, Himalayan rivers are the major contributors (Stoddart, 1969). The Himalayan and Tibetan regions cover only about $5 \%$ of the earth's land 
surface but supply about $25 \%$ of the dissolved load to the world ocean (Raymo and Ruddiman, 1992). Although, Himalayan region is hydrologically very important as it is the origin of three world's major river system viz. the Indus, the Ganges, and the Brahmaputra but very few studies have been reported on rainfall, runoff and its induced sediment yield processes in this region. In Himalayan or mountainous regions, the data whether on economic, social, or environmental are usually incomplete, when they exist at all. Therefore, lack of scientific knowledge about this planet's most complex landscape is main hurdle to plan the developmental agenda for this region.

Soil erosion involves the processes of detachment, transportation, and accumulation of soil from land surface due to either impact of raindrop, and shearing force of flowing water. Based on the processes considered, as well as the complexity, accuracy, scale (space and time), and ultimately data requirement, a wide range of models from simple empirical to complex physically based have been developed to model the soil erosion and subsequent sediment yield (Merritt et al., 2003; Aksoy and Kavvas, 2005). Simple and popular empirical models such as USLE and its derivatives perform very well at the plot scale (Risse et al., 1993; Angima et al., 2003). However, their use at catchment scale could be challenging. Therefore various physically based models such as Water Erosion Prediction Project (WEPP) (Nearing et al., 1989), Areal Non-point Source Watershed Environment Response Simulation (ANSWERS) (Beasley et al., 1980), Agricultural Nonpoint Source Pollution Model (AGNPS) (Young et al., 1989), Soil and Water Assessment Tool (SWAT) (Arnold et al., 1993), and many others have been developed and these have proved very useful as research tools. However, the use of physically based models is mostly limited to research due to their complexity and nonavailability of data required for field use. For example, WEPP model requires as many as 50 input parameters, which can cause the problem of equifinality (condition in which different combination of model parameters lead to similar output) (Brazier et al., 2000). Therefore, empirical models are most commonly used in field applications. However, these are based on inductive logic and generally applicable only to those conditions for which the parameters have been calibrated. Moreover, there is not a single model valid for all applications.

Sediment outflow from a watershed depends on several parameters which are responsible for the soil detachment and the transport capacity of the path followed by the eroded soil to reach the outlet. However, lack of detailed data with respect to these parameters at river catchment scale is a major constraint in estimation of sediment yield at catchment scale (Van Rompaey et al., 2001). Therefore, a simple empirical lumped sediment delivery ratio (SDR) approach is used to link the soil erosion within a watershed to the sediment yield at outlet (Ferro and Minacapilli, 1995). Since, SDR-based sediment yield estimation approach is an empirical lumped approach (Verstraeten and Poesen, 2001), it performs well only if the data of catchment belongs to inherent region. Applications of such empirical approach to other catchments are questionable and require rigorous calibration before extension. Also due to lumped nature of SDR approach, it is not helpful in prioritization of watershed management/treatment activities within a river basin/catchment. However, soil erosion and sediment yield exhibit large spatial variability due to heterogeneity involved in various parameters (catchment physical as well as climatic) responsible for theirs occurrence. The technique of Geographical Information System (GIS) is well suited for 
quantification of heterogeneity (not only in space but also in time) in the topographic, cover type, and drainage features of a watershed by partitioning the watershed into small homogenous grids (Jain et al., 2005; $\mathrm{Wu}$ et al., 2005; Naik et al., 2009). Furthermore, accessibility of data even in remote areas like Himalayan catchment is the major advantage of GIS and remote sensing (RS) techniques.

Keeping in view, limited data availability in Himalayan catchment and spatial variability and complexity involved in soil erosion and sediment production process, a simple spatially distributed model has been formulated in GIS environment. The model produces outputs showing spatial variability due to spatial discretization adopted and, therefore, helpful in mapping of sediment source and sink areas and prioritization of watershed management activities accordingly. However, model structure is kept simple so that the application of model can be easily extended in developing countries like India where availability of data in space and time is always a challenge.

\section{Model formulations}

The proposed model comprises of three major components (1) the assessment of seasonal gross soil erosion (GSE) for each grid/cell; (2) the assessment of seasonal local transport capacity (TC) for each grid/cell; and (3) transport limited accumulation algorithm for routing sediment from each of the discretized grid/cell to the outlet of the catchment by taking into account the local transport capacity of each cell.

\section{Estimation of gross soil erosion}

Universal Soil Loss Equation (USLE) has been found to produce realistic estimates of surface erosion over small size areas (Wischmeier and Smith, 1978; Jain and
Kothyari, 2000; Jain and Goel, 2002; Lee, 2004; Jain and Das, 2010). Although USLE is a lumped empirical model, this equation has been a part of several spatially distributed process-based models such as SWAT, AGNPS, CREAMS (Knisel, 1980), SEDNET (Prosser et al., 2001) and EPIC (Williams, 1983). This is possible due to the discretization of heterogeneous catchment into small homogeneous grids/cells. In this paper USLE is used for estimation of GSE within a cell is expressed as:

$\mathrm{GSE}_{\mathrm{i}}=\mathrm{RK}_{\mathrm{i}} \mathrm{LS}_{\mathrm{i}} \mathrm{C}_{\mathrm{i}} \mathrm{P}_{\mathrm{i}}$

Where, $\mathrm{GSE}_{\mathrm{i}}=$ gross amount of soil erosion in cell $i$ (MT ha year $\left.^{-1}\right) ; \mathrm{R}=$ rainfall erosivity factor ( $\mathrm{MJ} \mathrm{mm} \mathrm{ha}{ }^{-1} \mathrm{~h}^{-1}$ year $\left.^{-1}\right) ; \mathrm{K}_{\mathrm{i}}=$ soil erodibility factor in cell $i$ (MT ha $\mathrm{h} \mathrm{ha}^{-1}$ $\left.\mathrm{MJ}^{-1} \mathrm{~mm}^{-1}\right) ; \mathrm{LS}_{\mathrm{i}}=$ slope steepness and length factor for cell $i$ (dimensionless); $\mathrm{C}_{\mathrm{i}}=$ cover management factor (dimensionless) and $\mathrm{P}_{\mathrm{i}}=$ supporting practice factor for cell $i$ (dimensionless).

\section{Assessment of seasonal sediment transport capacity}

Sediment transport capacity expresses the erosive power of overland flow or channel flow which is responsible for the movement of eroded soil. In fact, the process of soil erosion and deposition is governed by the sediment transport capacity of overland flow and subsequent channel flow. Therefore, sediment transport capacity equation is an essential part of all physically based sediment yield computation models. Several simple to complex equations have been developed for estimation of transport capacity of different $\mathrm{grid} / \mathrm{cell}$ within the catchment. One of the most commonly used transport capacity equation as given by Van Rompaey et al., (2001) is as follows:

$\mathrm{TC}=\mathrm{K}_{\mathrm{TC}} \mathrm{RK}\left(\mathrm{LS}-\mathrm{aS}_{\mathrm{IR}}\right)$ 
Where, TC is the transport capacity $\left(\mathrm{kg} \mathrm{m}^{-2}\right.$ year $\left.^{-1}\right) ; \quad \mathrm{K}_{\mathrm{TC}}$ is the transport capacity coefficient and $S_{I R}$ is the inter-rill slope gradient factor. Van Rompaey et al., (2005) reported poor performance $(\mathrm{R}=0.25)$ while using this equation in mountainous part of an Italian catchment. Normally, the topography of hilly areas is such that flow converges at some locations, generally at the junction of the steep slope and valley floor (or toe of the slope). These locations are generally the end points of the steep slopes or where sudden flattening in the slopes is observed. As per equation 2 model estimates low values of transport capacity of theses points due to low values of slopes (S). Hence, most of the eroded sediment will be deposited at theses points and model underestimates sediment outflow. However, in reality these are intense flow convergent points and hence attributed to high transport capacity. To overcome this problem Verstraeten (2007) suggested to incorporate an upslope contributing area factor in transport capacity equation. After incorporating an upslope contributing area factor Equation 2 can be re-written as follows:

$\mathrm{TC}_{\mathrm{i}}=\mathrm{K}_{\mathrm{TC}} \mathrm{RK}_{\mathrm{i}} \mathrm{S}_{\mathrm{i}}^{\beta} \mathrm{A}_{\mathrm{si}}^{\gamma}$

Where, $\mathrm{A}_{\mathrm{si}}$ is the upslope contributing area for cell $i$ which represents the actual flow accumulation value of any cell. Incorporation of upslope contributing area factor in transport capacity equation (Equation 3), transport capacity of intense flow convergent areas will be increased significantly even sudden fallen in slope $(\mathrm{S})$.

\section{Sediment routing using transport limited accumulation}

Eroded sediment from each cell follows a definite path defined by direction of flowing water. The amount of sediment outflow from one cell to its downstream cell depends on local sediment transport capacity (TC) for a cell. If the local TC is smaller than the sediment flux, then sediment deposition is modeled. If $\mathrm{TC}$ is higher than the sediment flux, then sediment transport will be supply limited. Thus, by introducing the transport capacity, a more realistic representation of overland flow in sediment transport can be simulated. The model produces different maps of erosion, sediment transport, and sediment deposition rates. For cell-based discretization system, transport limited accumulation can be computed as:

$$
\begin{aligned}
& \mathrm{T}_{\text {out }_{\mathrm{i}}}=\min \left(\mathrm{GSE}_{\mathrm{i}}+\sum \mathrm{T}_{\mathrm{in}_{\mathrm{i}}}, \mathrm{TC}_{\mathrm{i}}\right) \\
& \mathrm{D}_{\mathrm{i}}=\mathrm{GSE}_{\mathrm{i}}+\sum \mathrm{T}_{\mathrm{in}_{\mathrm{i}}}-\mathrm{T}_{\text {out }_{\mathrm{i}}}
\end{aligned}
$$

where $\mathrm{T}_{\mathrm{in} i}=$ sediment inflow from upstream cells, $\mathrm{T}_{\text {out }}=$ sediment outflow from the cell $i$. $\mathrm{D} i=$ deposition in cell $i$.

\section{Study area and data used}

The proposed model has been used to model the sediment yield from a hilly watershed named Naula with elevation ranging from 790 $\mathrm{m}$ to $3088 \mathrm{~m}$ and geographically located between $29^{\circ} 44^{\prime} \mathrm{N}$ and $30^{\circ} 6^{\prime} 20^{\prime \prime} \mathrm{N}$ latitudes and $79^{\circ} 06^{\prime} 15^{\prime \prime} \mathrm{E}$ and $79^{\circ} 31^{\prime} 15^{\prime \prime} \mathrm{E}$ longitudes in the middle Himalayan region of Uttarakhand state of India (Figure 1). Naula watershed is a hydrologically important sub-watershed of Ramganga reservoir catchment (3134 square $\mathrm{km}$ area). Ramganga reservoir, a multipurpose project (127 meter heigh earth and rockfill dam) of Government of India built in year 1974, produces approximately $452 \mathrm{MW}$ of electricity and also facilitates irrigation on an area of about 5120 square km during nonmonsoon period. Naula watershed covers most of the hilly portion of Ramganga catchment (1084 square $\mathrm{km}$ drainage area) and is the largest sediment contributor to the reservoir. The topography of the watershed is undulating and irregular with slope varying from moderate to steep. Daily rainfall data of 
ten raingauge stations located inside/outside of Naula watershed were collected from the Divisional Forest Office (Soil Conservation) Ranikhet, Government of Uttarakhand and used to calculate the weighted rainfall of Naula watershed. There are four sediment monitoring sites in the Naula watershed. Three sediment units i.e., Mehalchauri (166 square $\mathrm{km}$ ), Chaukhutia (572 square $\mathrm{km}$ ) and Naula (1084 square $\mathrm{km}$ ) are located on the main Ramganga stream.

However, Buda Kedar (295 square km) sediment unit is located on Bino river, a tributary of Ramganga river. Daily sediment data of four gauging stations, namely Naula, Buda Kedar, Chaukhutia and Mahalchauri were also collected from the same agency.

\section{Generation of input geo-database}

Extraction of drainage network and watershed from Digital Elevation Model (DEM)

Conventionally DEM is prepared by digitization of the contour lines from toposheets of the study area. However, digitization of contour lines from toposheets is very painstaking and time consuming process, especially when the area of interest is large and hilly (not easy to access). It is better to use the Shuttle Radar Topographic Mission (SRTM) DEMs if cartographic data with scale above 1:25,000 is not available (Jarvis, 2004). Therefore, in this study, SRTM DEM data of 3-arc second (90m X 90m) spatial resolution was downloaded from www.landcover. org/data/srtm/ and used.

Watershed boundary, drainage pattern and slope/gradient map, have been extracted from the DEM with the help of DEM Hydro processing tools available in GIS (ArcGIS ver. 9.3). All these maps are required as input of the model at different stages.

\section{Rainfall erosivity (R)}

Rainfall erosivity or erosion index is one of the important parameters in estimation of soil loss from USLE. Ram Babu et al., (2004) found linear relationship when annual and seasonal erosion index values were plotted against annual and seasonal rainfall, respectively. On the basis of these linear relationships they plotted iso-erodent maps for different zones viz., northern, western, central, eastern, and southern India. In the present study, rainfall erosivity was calculated by the relationship developed by Ram Babu et al., (2004) for this particular zone of India and presented as:

$\mathrm{R}=71.9+0.361 \mathrm{P} \quad(\mathrm{r}=0.91$, for $293 \leq \mathrm{P} \leq 3190)$

Where, $\mathrm{P}$ is the average seasonal rainfall in $\mathrm{mm}$. In the present study, Equation 6 is used to compute seasonal values of $\mathrm{R}$-factor by replacing $\mathrm{P}$ with observed seasonal rainfall of a particular year.

\section{Soil erodibility $(\mathbf{K})$}

Soil map of the watershed was prepared by digitization of soil maps available in survey report obtained from National Bureau of Soil and Landuse Planning (NBSS and LUP, 2004) using ArcGIS ${ }^{\circledR}$. The digitized polygon map of Naula watershed was then rasterized at $90 \mathrm{~m}$ grid cells by using vector to raster tool. Based on the soil characteristics such as texture, depth, erosion, surface, drainage, and slope (NBSS and LUP, 2004), total nine soil mapping units have been identified in the entire study area. Details such as fraction of sand, silt, clay and organic matter and other related parameters information for different mapping units are taken from NBSS and LUP (2004) for Naula watershed. Kvalues for different soil categories were calculated according to the procedure given by Haan et al., (1994). 


\section{Length-Slope factor (LS)}

The combined length-slope (LS) factor in USLE is a measure of the sediment transport capacity of overland flow and it reflects the effect of topography on soil erosion. However, several methods (Wischmeier and Smith, 1978; Moore and Burch, 1986a, b; Moore and Wilson, 1992; Desmet and Govers, 1996) have been developed for estimation of LS factor but application of these to real landscapes as part of a GIS is a major problem. Among these, the one which is best suited for integration with the GIS is the theoretical relationship proposed by Moore and Burch (1986a, b) and Moore and Wilson (1992) based on unit stream power theory, given as:

$$
\mathrm{LS}_{\mathrm{i}}=\left[\frac{\mathrm{A}_{\mathrm{si}}}{22.13}\right]^{\mathrm{n}}\left[\frac{\sin \theta_{\mathrm{i}}}{0.0896}\right]^{\mathrm{m}}
$$

Where, $\mathrm{A}_{\mathrm{si}}$ is the specific area at cell $i$ defined as the upslope contributing area for overland grid $\left(\mathrm{A}_{\mathrm{up}}\right)$ per unit width normal to flow direction; $\theta_{i}$ is the slope gradient in degrees for cell $i$.

In the original equation of LS factor (Wischmeier and Smith, 1978), slope length $(\lambda)$ is defined as the distance from the point of origin of overland flow to the point where either the slope gradient decreases sufficiently for deposition to begin or runoff water enters a well-defined channel. In the present study the slope length $(\lambda)$ is replaced by the unit upslope contributed area at which formation of channel is started and taken equal to channel/stream initiation threshold value (ESRI, 1994; Jain and Kothyari, 2000). The main aim of the replacement of slope length by upslope contributing area is to incorporate the effect of converging and diverging terrain on soil erosion and hydrological aspect of the watershed (Moore and Wilson, 1992). The stream generation threshold or channel initiation threshold is a numerical value; pixels having flow accumulation value less than channel initiation threshold are termed as overland flow pixels and those having higher flow accumulation value than channel initiation threshold are termed as channel/stream pixels. The threshold has to be chosen in such a way that the total stream length generated using threshold and channel network seen in satellite data and survey of India (SOI) toposheets (digitized in vector form) are equivalent. Accordingly, a channel initiation threshold value of 0.486 square $\mathrm{km}$ is adjudged appropriate to define channel cells for Naula watershed.

\section{Crop management factor (C)}

To assign the spatial values of crop management factor $(\mathrm{C})$, land use map of the study area was prepared by classification of LANDSAT TM satellite image using unsupervised and supervised classification in ERDAS image processing software. To discriminate the vegetation from other surface cover types, the Tasselled Cap Transformations (TCT), Vegetation Index (VI), and Water Index (WI) were performed. Overall, six different classes viz., forest, agriculture, river bed, pasture, water and settlement are identified in the study area with the help of limited ground truth information, Google Earth image and SOI topographic maps. Table 1 represents different land use classes that exist in Naula and its subwatersheds. Based on the land cover categories, the attribute values for the $\mathrm{C}$ factor are assigned to individual cells from the tabulated values suggested by Wischmeier and Smith (1978), Singh et al., (1992), Haan et al., (1994).

\section{Management practice factor $(\mathbf{P})$}

Based on experimental investigations, values for P-factor have been tabulated for many management conditions (Haan et al., 1994). 
The P-factor is taken equal to 0.7 for agricultural land as mostly contour cultivation is followed on agricultural land in the study area, and unity for other land use/land cover types. P-factor values are added in the attribute field of land use map.

Model applications and discussion of results

\section{Generation of gross soil erosion maps}

The layers of topographic factor (LS), crop management factor $\mathrm{C}$, soil erodibility factor $\mathrm{K}$, and support practice factor $\mathrm{P}$ are overlaid using ArcGIS. For estimation of gross soil erosion in the watershed for different years/season, the composite map of KLSCP factor is multiplied by R-factor in raster calculator of ArcGIS. Figure 2 represents gross soil erosion map of Naula watershed for the year 1987 as illustration.

\section{Generation of transport capacity maps}

Transport capacity of overland flow was calculated for each season and each pixel using Equation (3) in ArcGIS. Goodness of fit criteria such as Model Efficiency (ME), (Nash and Sutcliffe, 1970) and Relative Root Mean Square Error (RRMSE) have been used to calibrate the value of $\mathrm{K}_{\mathrm{TC}}$ appearing in Equation (3) using five year observed and computed sediment outflow data (estimated from Equation 4). Model efficiency (ME) can be calculated as follows:

$$
\mathrm{ME}=1-\frac{\sum\left(\mathrm{Y}_{\mathrm{obs}}-\mathrm{Y}_{\mathrm{pred}}\right)^{2}}{\sum\left(\mathrm{Y}_{\mathrm{obs}}-\mathrm{Y}_{\text {mean }}\right)^{2}}
$$

Where, $\mathrm{Y}_{\mathrm{obs}}$ observed seasonal sediment (tons), $\mathrm{Y}_{\text {pred }}$ is predicted seasonal sediment (tons), $\mathrm{Y}_{\text {mean }}$ is mean of the observed sediment (tons). Value of $\mathrm{ME}$ ranges from $-\infty$ to 1 . Values close to 1 indicate better model fit.
However the negative value of ME implies inefficiency of the model in prediction. Relative Root Mean Square Error is estimated by the following formula:

$\operatorname{RRMSE}=\frac{\sqrt{\frac{1}{n} \sum_{i=1}^{n}\left(Y_{o b s}-Y_{p r e d}\right)^{2}}}{\frac{1}{n} \sum_{i=1}^{n} Y_{o b s}}$

Where, $n$ is the number of data points. For wide range of $\mathrm{K}_{\mathrm{TC}}$, value of $\mathrm{ME}$ (Equation 8) and RRMSE (Equation 9) have been calculated and shown in figure 3. It is evident from figure 3 that at $\mathrm{K}_{\mathrm{TC}}=3 \times 10^{-5}$, ME is the highest (0.74) and RRMSE is at the lowest $(0.29)$. Any change in the value of $K_{T C}$ $\left(=3 \times 10^{-5}\right)$ leads to increase and decrease in RRMSE and ME, respectively. It is worth noting that final calibrated $\mathrm{K}_{\mathrm{TC}}$ value $\left(=3 \times 10^{-}\right.$ ${ }^{5}$ ) in this case is close to $\mathrm{K}_{\mathrm{TC}}$ obtained by Verstraeten (2007) for good to moderate vegetation. Notably, about $46 \%$ area of the study watershed is covered by the forest. Transport capacity maps are generated using calibrated $\mathrm{K}_{\mathrm{TC}}$ value for all years (1979-87). Transport capacity map for year 1987 is presented in figure 4 as illustration. It is evident from this figure that the ridges and the flattened area near the channel, generally cultivated (viz., south-west direction of Chaukhutia gauging site) are the areas possessing low transport capacity. However, transport capacity is high in channel areas and the steep head water areas.

\section{Sediment routing considering local transport capacity}

Gross soil erosion was estimated using raster calculator tool of ArcGIS, but the quantity of eroded soil delivered to the next cell will depend on the transport capacity of the cell. However, at present there is no ready to use tool available in GIS, which estimates the 
quantity of sediment moved in the next cell by considering gross soil erosion and transport capacity of the cell. Therefore using the basic principal of overland flow routing (Equation 4) a programme was developed in Interactive Data Language (IDL).

The developed tool/ programme estimates the sediment moved out from each pixel using flow direction, flow accumulation, gross soil erosion, and transport capacity maps. Tool compares the gross soil erosion (total soil ready to move out of a particular pixel) and transport capacity of the flow in that pixel, if transport capacity is equal or greater than gross soil erosion then entire eroded soil will be transported into the next pixel.

The destination of this transported soil/sediment will be determined using flow direction map. However, if the transport capacity of any pixel is less than total soil ready to move out of particular pixel, the tool will assign the difference between transport capacity and the total soil ready to move out, as amount of sediment deposited in that pixel. Batch processing option is given in programme to process temporal data and to save time in repeated operations/processes.

Using developed tool, sediment outflow maps for different years (1979-87) were produced. Such maps provide the amount of sediment outflow from the system at every cell and are useful for determination of sediment flowing out of the watershed at any location.

Figure 5 depicts the sediment outflow map for the year 1987 as illustration. While cell values of Naula site from theses maps were read for validation period and compared with observed sediment data, a very low errors have been observed $(26.1 \%, 9.0 \%$, and $0.2 \%$ for 1985 , 86 , and 87, respectively). Such low errors in estimation of sediment yield do support the efficacy of the model.

\section{Investigation of spatial distribution capability of model}

Comparison of sediment yield at outlet of the watershed is not sufficient for validation of a spatially distributed sediment model (Takken et al., 1999) due to highly complex behaviour of sediment. Therefore, to investigate the spatial distribution capability of the proposed model, the data of three upstream gauging sites (Mehalchauri, Buda Kedar, and Chaukhutia) are used to check the prediction capability of the proposed model. Sediment yield estimated by the developed model for all these subwatersheds/gauging sites can be read directly from the corresponding pixel value from sediment outflow map of Naula watershed. When sediment yields at these gauging sites were compared with the corresponding observed values for different years, it was found that in most cases, the model performed very well $(74 \%$ data points within $\pm 30 \%$ error range, figure 6 ). However, large error during a particular year may be attributed to uncertainties in observations probably due to temporal variability involved in sediment yield. Furthermore, in the present study a single vegetation map is used for all years and for entire season, however vegetation has dynamic nature. Finally, considering all data points, the accuracy obtained is considered well and acceptable because even the more elaborate processbased soil erosion models are found to produce results with still larger errors (ASCE, 1975; Foster, 1982; Wu et al., 1993; Wicks and Bathurst, 1996).

\section{Generation of vulnerability maps of net erosion/deposition}

Using Equation 5, sediment deposition maps for various years were obtained. Net soil erosion/deposition maps of various years were produced by superimposing sediment deposition maps over gross erosion map of 
corresponding years. Such maps are helpful in identifying areas vulnerable to soil erosion and sediment deposition in watershed area. Figure 7 depicts net soil erosion/sediment deposition map for year 1987 as illustration. As can be seen in figure 7 , deposition of sediment resulted near the banks of some of the stream reaches where transport capacity was low. It is possible to identify the critical areas delivering most of the sediment to the river system. Notably, these areas are not necessarily the same as those producing most erosion, as most of the eroded sediment is deposited within the catchment, before reaching the river system. The net erosion estimated on a cell basis for the watershed is grouped into the following scales of severity of erosion: Slight ( 0 to $5 \mathrm{t} \mathrm{ha}^{-1}$ year $^{-1}$ ), Moderate (5 to $10 \mathrm{t} \mathrm{ha}^{-1}$ year $^{-1}$ ), High (10 to $20 \mathrm{t} \mathrm{ha}^{-1}$ year $^{-1}$ ), Very High (20 to $40 \mathrm{t} \mathrm{ha}^{-1}$ year ${ }^{-1}$ ), Severe (40 to $80 \mathrm{t} \mathrm{ha}^{-1}$ year ${ }^{-1}$ ) and Very Severe (> $80 \mathrm{t} \mathrm{ha}^{-1}$ year $^{-1}$ ) as per the guidelines suggested by Singh et al., (1992) for Indian conditions. The same is also depicted in table 2 and figure 7 for Naula and its subwatersheds. A significant area $(6.4 \%$ of total watershed area) of the Naula watershed is under deposition (Table 2). As can be seen from figures 7 , most of the deposition of sediment occurred in the sides of the drainage channels when they reach in valleys and also on flatter land areas found in the cultivated valley lands.

Table.1 Land use pattern in Naula and its subwatersheds

\begin{tabular}{lcccc}
\hline \multirow{2}{*}{ Landuse } & \multicolumn{4}{c}{ \% of watershed area } \\
\cline { 2 - 5 } & Naula & Chaukhutia & Buda Kedar & Mehalchauri \\
\hline Forest & 46.44 & 59.29 & 33.93 & 50.64 \\
Agriculture & 23.07 & 14.65 & 33.53 & 20.64 \\
River bed & 6.37 & 5.57 & 7.06 & 3.15 \\
Pasture & 22.91 & 19.51 & 24.05 & 24.18 \\
Water & 0.2 & 0.11 & 0.19 & 0.04 \\
Settlement & 1.01 & 0.86 & 1.23 & 1.35 \\
\hline
\end{tabular}

Table.2 Area (\%) under different soil erosion/deposition classes in Naula and its sub-watersheds

\begin{tabular}{lccccccc}
\hline \multirow{2}{*}{ Watershed } & \multicolumn{7}{c}{ Erosion/Deposition Classes } \\
\cline { 2 - 8 } & Deposition & Slight & Moderate & High & Very High & Severe & Very Severe \\
\hline Naula & 6.4 & 84.7 & 3.0 & 1.8 & 1.4 & 1.3 & 1.5 \\
Buda Kedar & 7.0 & 82.4 & 3.7 & 2.2 & 1.4 & 1.6 & 1.7 \\
Chaukhutia & 5.4 & 86.2 & 2.8 & 1.7 & 1.3 & 1.1 & 1.6 \\
Mehalchauri & 4.8 & 89.1 & 1.7 & 1.1 & 1.4 & 1.1 & 0.7 \\
\hline
\end{tabular}


Figure.1 Location map of Naula watershed

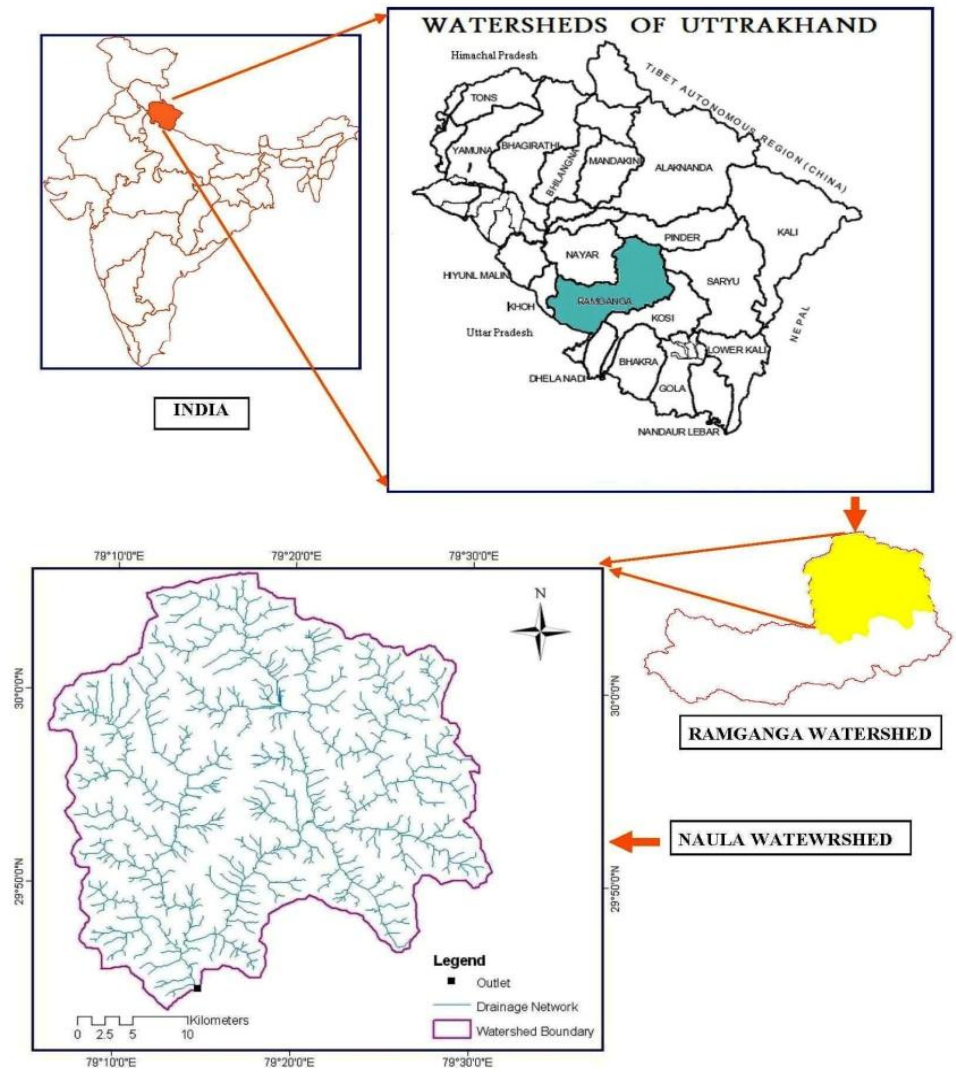

Figure.2 Gross soil erosion map of Naula watershed

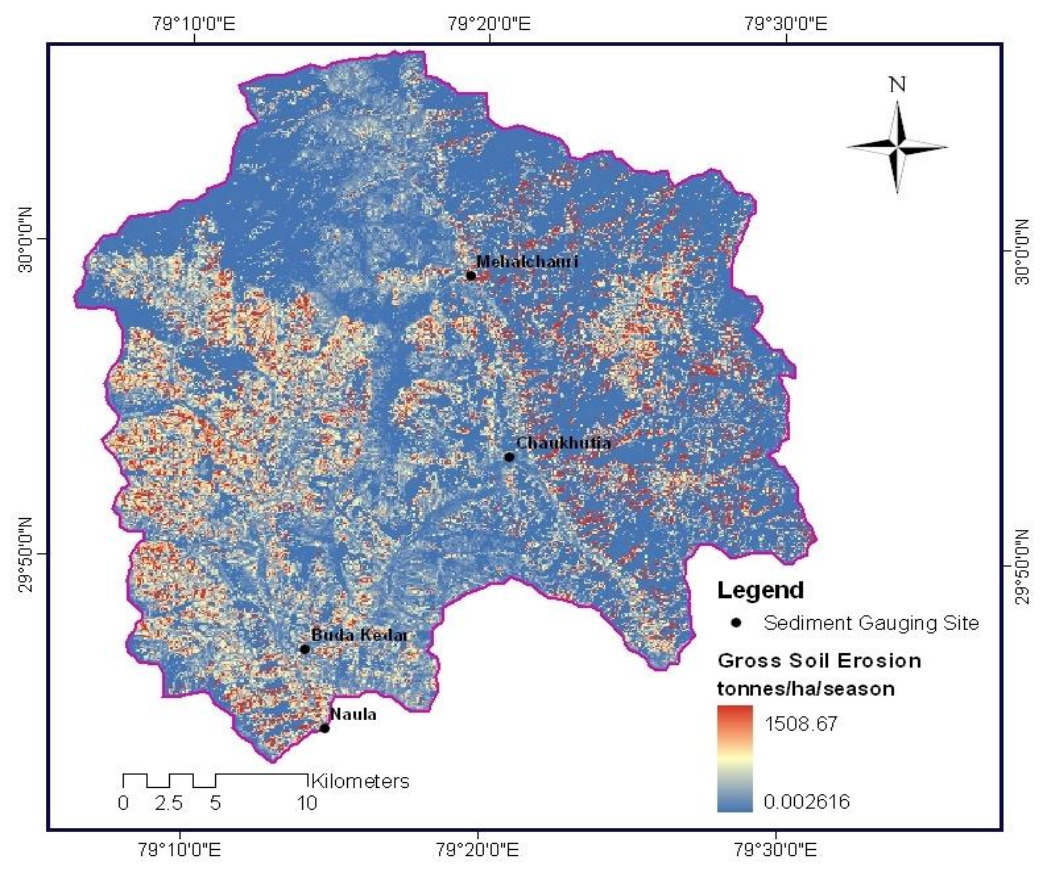


Figure.3 Calibration of KTC for Naula watershed using seasonal rainfall-sediment yield data

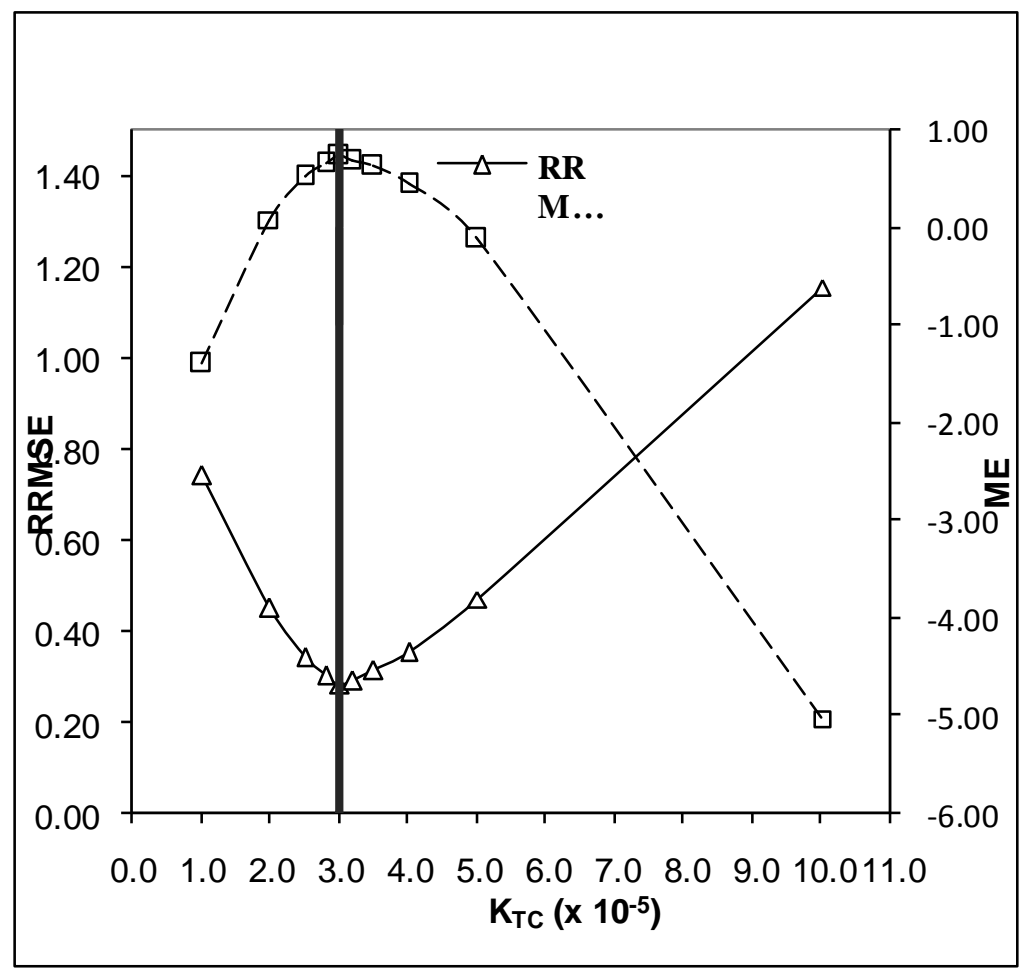

Figure.4 Transport capacity map of Naula watershed

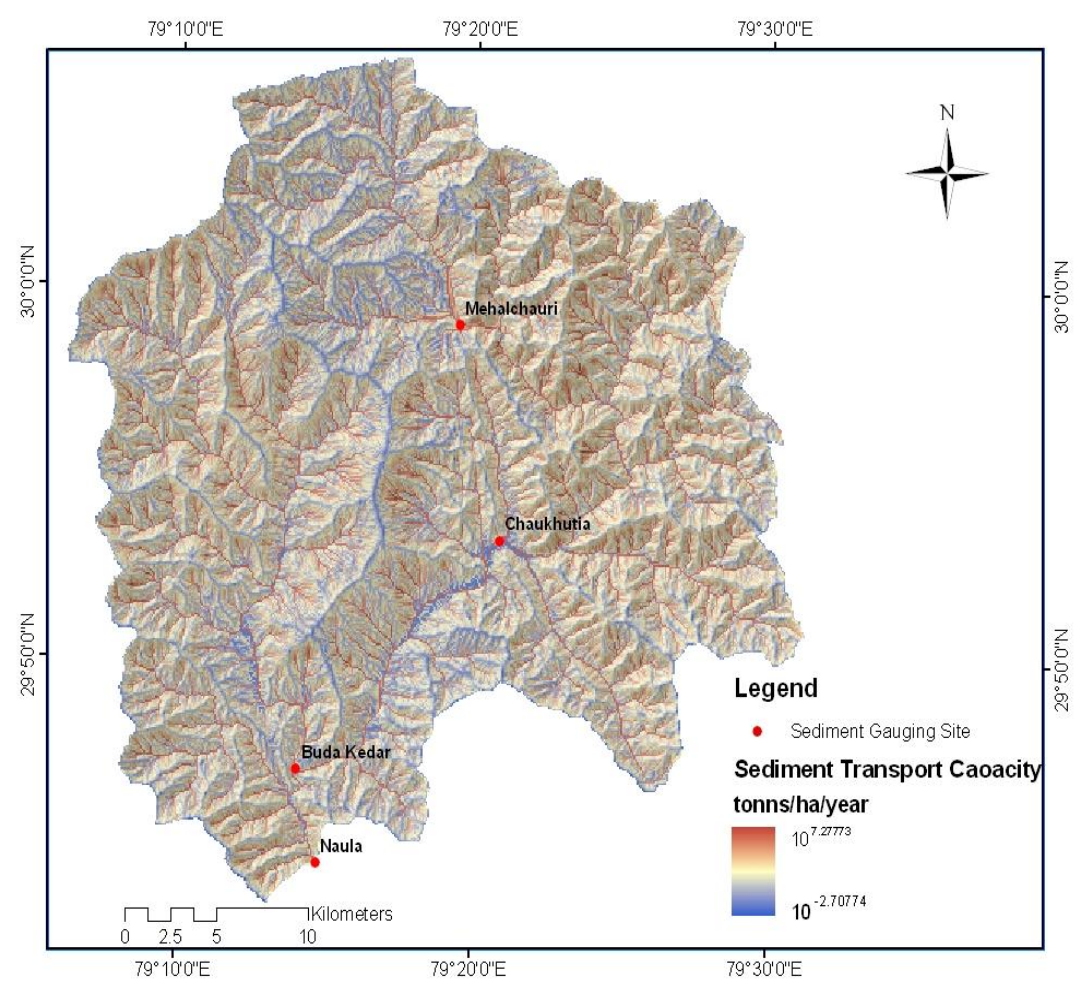


Figure.5 Sediment outflow map of Naula watershed

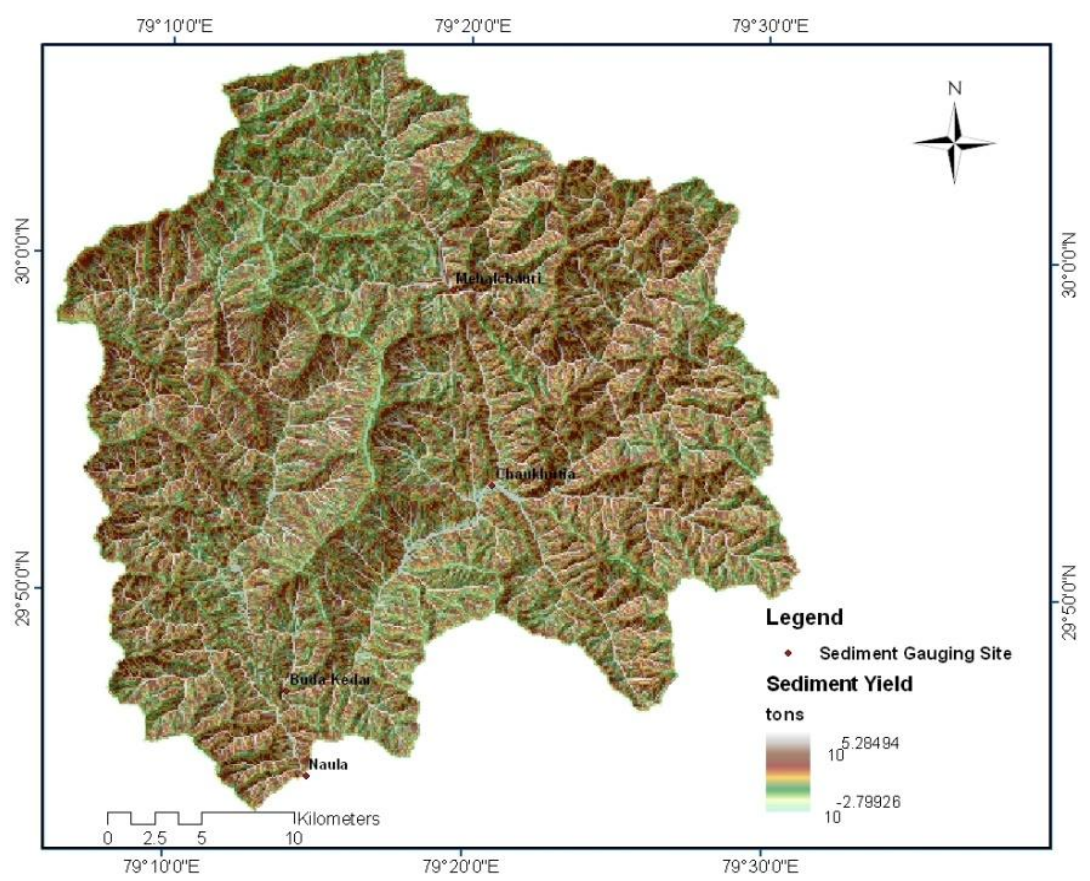

Figure.6 Comparison between observed and predicted values of sediment outflow at different gauging sites

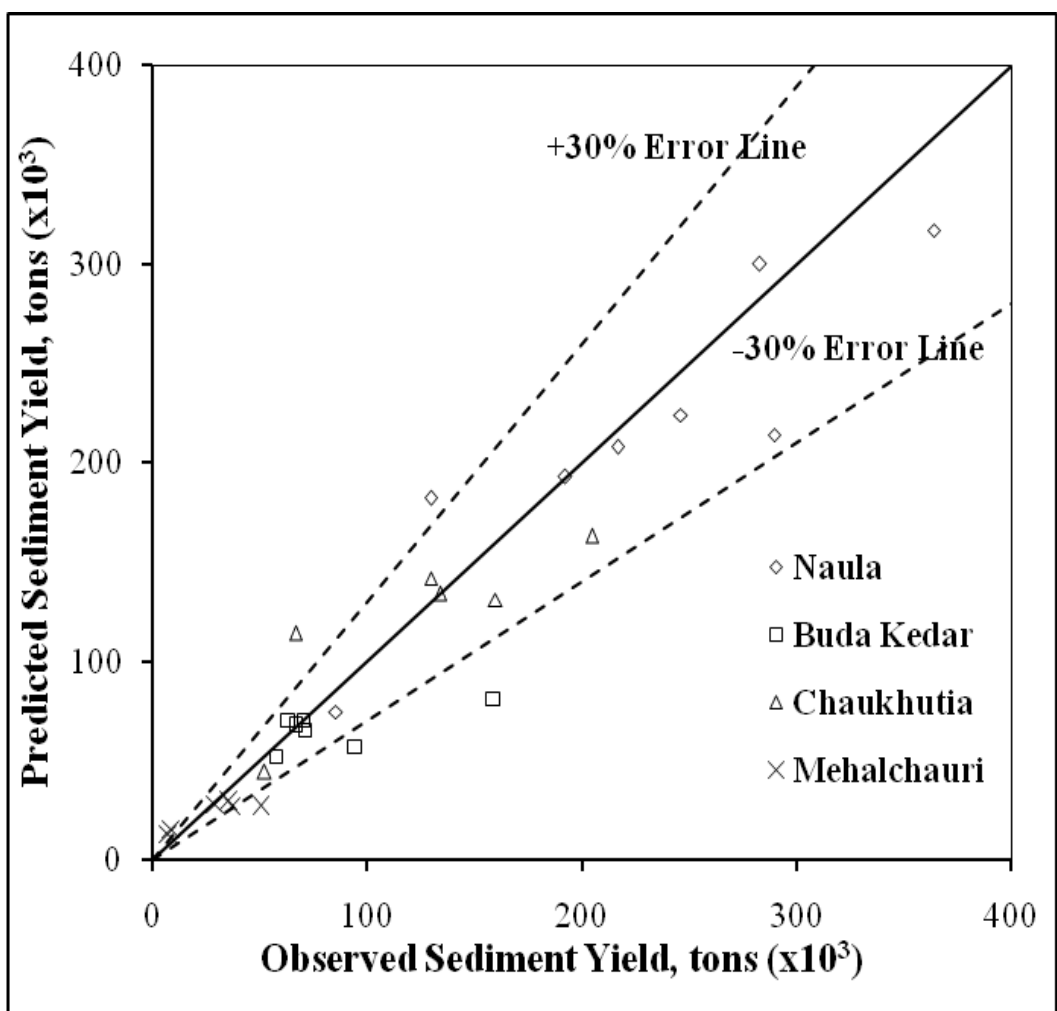


Figure.7 Net erosion/deposition map of Naula watershed

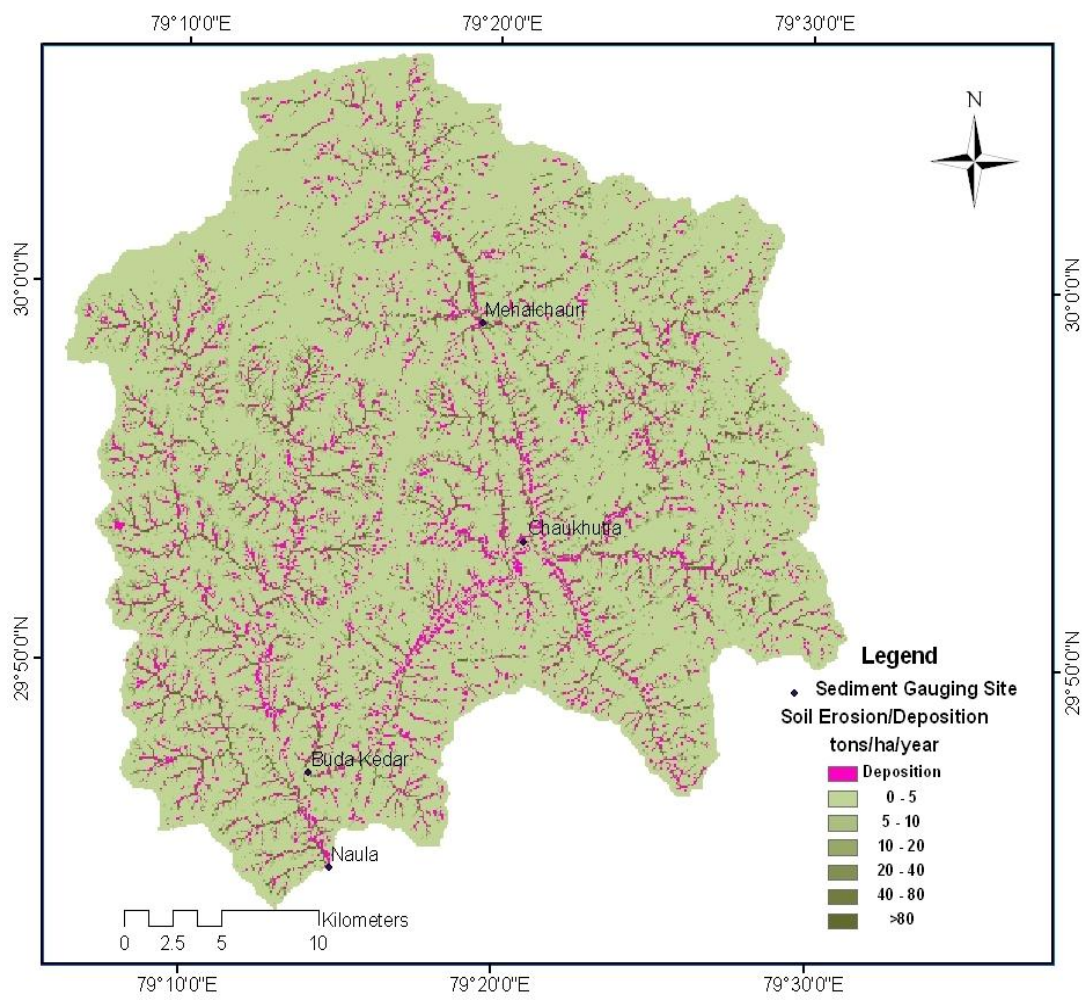

It was estimetd that soil loss in $9.0 \%$ area of Naula watershed is above soil loss tolerence limit. Notable that soil tolerance limit is defined as the acceptable rate of soil erosion at which the quality of a soil as medium for plant growth can be maintained. Mandal and Sharda (2011) found soil tolerance limit 5 ton/ha/year for this particular region. According to table 2 Buda Kedar watershed is most sensitive to erosion as well as deposition, and however, Mehalchauri is least sensitive for erosion/deposition. The region is clear that Buda kedar consists only 33.9\% forest area, however, Mehalchuair comprises $50.6 \%$ forest area. Beside this, a large part of Buda Kedar watershed is under agricuture.

Worth notable that during tillage operations, land is exposed and loosened and become more suspectible for the erosion. The field verfication confirmed that erosion and associated sediment deposition had indeed occur in these areas. Such categorizations of net soil erosion as illustrated in figure 7 can be of immense significance in deciding the priority levels for implementation of the suitable measures (biological or engineering) for watershed treatment.

\section{Usefulness of the study and conclusions}

On-site erosion reduces the soil quality due to removal of nutrient rich top soil layer and also reduces the water holding capacity of many soils. Therefore, in developing countries like India, where rural population is more than $65 \%$ and land is the identity of the people, assessment of erosion focuses mainly on the on-site effects of erosion. It is evident from the literature (Singh, 2006) that productivity can be increased by bringing the soil loss near or below the soil tolerance limit. Therefore, comparison between soil tolerance limit and prevailing soil loss can be the best criteria for deciding the priority areas as well as treatment activities within the watershed. In 
the present study, the formulated model has potential to identify the areas where soil loss exceeding the permissible/tolerance limit (9\% area of study watershed has been identified in the present study) and these are the areas where immediate soil conservation measures have to be implemented. In the nutshell, our target should to bring the soil loss within the soil loss tolerance limit which will certainly lead to sustainable agricultural production system.

In the present era of industrialization, more attention is being paid to the society at large, viz., in flood prevention, water reservoir preservation, and water pollution control (Garen et al., 1999). However, it has been observed that sedimentation in the reservoirs have occurred at a much faster rate than anticipated. In view of the stupendous task of construction and the huge cost involved in hydro-power projects, ensuring longevity of the reservoir have become the cause of major concern to the planners and administrators. Nevertheless, sedimentation data from number of projects indicated that the actual sediment production rates (SPR) have been much more than the assumed rates. The erosion/deposition maps derived by the formulated model in the present study exhibit sediment rate at a particular cell in spatial domain, and the value at the outlet cell indicate the sediment outflow from the entire watershed. The sediment outflow at any point may be quite helpful in planning to design sediment production rate (SPR) for a hydropower project at that location. However, sites identified vulnerable to soil deposition from such maps could be avoided for planning sites for multipurpose projects where huge amount of storage of water is required.

Whether the main concern of soil and water conservation planning is towards prevention of on-site or off-site effects of erosion, there was a growing need for tools that enable to define the spatial distribution of erosion within a catchment i.e to identify sources of sediment erosion. The formulated model involving only elementary processes responsible for soil erosion and subsequently sediment deposition is capable to capture the spatial patterns of soil erosion as well as lumped sediment load in the entire watershed up to a cell area $(90 \mathrm{~m} \times 90 \mathrm{~m})$. Formulated model is more rational and pragmatic than the lumped Sediment Delivery Ratio (SDR) approach. Worth notable that GIS and remote sensing techniques are capable to access data in tough terrain and adverse climatic conditions, since, model requires input data in the form of different thematic GIS layers, model has potential to be applied for any watershed, in terms of size and location, throughout the globe. Moreover, the model may be a useful tool in sustainable environmental watershed management planning.

\section{References}

Aksoy, H., Kavvas, M.L. 2005. A review of hillslope and watershed scale erosion and sediment transport models. Catena, Vol. 64, pp. 247- 271.

American Society of Civil Engineers (ASCE), 1975. Sedimentation Engineering. American Society of Civil Engineering, New York: NY.

Angima, S.D., Stott, D.E., O'Neill, M.K., Ong, C.K., Weesies, G.A, 2003. Soil erosion prediction using RUSLE for central Kenyan highland conditions. Agric. Ecosystems Environ., Vol. 97(13), pp. 295-308.

Arnold, J.G., Engel, B.A., Srinivasan, R., 1993. Continuous-time, grid cell watershed model. In: Proceedings of the Conference, Spokane, WA, June 18-19, pp. 267-278.

Beasley, D.B., Huggins L.F., Monke, E.J. 1980. ANSWERS - a model for watershed planning. Transactions of American Society of agricultural 
Engineers, Vol. 23, pp. 938-944.

Brazier, R.E., Beven, K.J., Freer, J., Rowan, J.S. 2000. Equifinality and uncertainty in physically-based soil erosion models: application of the GLUE methodology to WEPP, the Water Erosion Prediction Project for sites in the UK and USA. Earth Surf Process Landform, Vol. 25, pp. 825-845.

Desmet, P.J., Govers, G, 1996. A GISprocedure for the automated calculation of the USLE LS-factor on topographically complex landscape units. J. Soil and Water Conservation. Vol. 51, pp. 427-433.

ERDAS (Earth Resources Data Analysis System), 2005. ERDAS Imagine 8.6, Users Manual. ERDAS Inc.: Atlanta, GA.

ESRI (Environmental Systems Research Institute), 1994. Cell based modeling with GRID. Environmental Systems Research Institute Inc., Redlands, California, USA.

Ferro, V., Minacapilli, M. 1995. Sediment delivery processes at basin scale. Hydrological Sci. J., Vol. 40, No. 5, pp. 703-717.

Foster G.R, 1982. Modelling the erosion processes. In Hydrological Modelling of Small Watersheds, Haan CT, Johnson $\mathrm{H}$, Brakensiek DL (eds). ASAE Monograph No. 5, American Society of Agricultural Engineers, St. Joseph, MI; 297-380.

Garen, G., Woodward, D., Geter, F. 1999. A user agency's view of hydrologic, soil erosion and water quality modelling. Catena, Vol. 37, pp: 277-289.

Haan, C.T., Barfield, B.J., Hayes, J.C. 1994. Design Hydrology and Sedimentology for Small Catchments. Academic Press, New York.

Jain, M.K., Das, D, 2010. Estimation of sediment yield and areas of soil erosion and deposition for watershed prioritization using GIS and remote sensing. Water Resource Management, Vol. 24, No. 10, pp. 2091-2112.

Jain, M.K., Kothyari, U.C., 2000. Estimation of soil erosion and sediment yield using GIS. Hydrol. Sci. J., Vol. 45, No. 5, pp. 771-786.

Jain, M.K., Kothyari, U.C., Ranga Raju, K.G, 2005. Geographic information system based distributed model for soil erosion and rate of sediment outflow from catchments. J. Hydraulic Engineering, ASCE, Vol. 131, pp. 755-769.

Jain, S.K. Goel, M.K, 2002. Assessing the vulnerability to soil erosion of the Ukai Dam catchments using remote sensing and GIS. Hydrol. Sci., Vol. 47, No. 1, pp. 31-40.

Jarvis, A., Rubiano, J., Nelson, A., Farrow, A., Mulligan, M, 2004. Practical use of SRTM data in the tropics: comparisons with digital elevation models generated from cartographic data. Cali: Centro Internacional de Agricultura Tropical (CIAT), Working document, 198, 32.

Knisel, W.G. 1980. CREAMS: a field-scale model for chemical, runoff and erosion from agricultural management systems. Conservation Research Report No. 26, South East Area, US Department of Agriculture, Washington, DC.

Lee, S. 2004. Soil erosion assessment and its verification using the universal soil loss equation and geographic information system: a case study at Boun, Korea. Environ. Geol, Vol. 45, No. 3, pp. 457465.

Mandal, D., Sharda, V.N. 2011. Assessment of permissible soil loss in India employing a quantitative bio-physical model. Curr. Sci., Vol. 100, No. 3, pp: 383-390.

Merritt, W.S., Latcher, R.A., Jakeman, A.J., 2003. A review of erosion and sediment transport models. Environ. Modelling and Software, Vol. 18, pp. 761-799. 
Moore, I., Burch, G., 1986a. Physical basis of the length-slope factor in the universal soil loss equation. Soil Sci. Society of America J., Vol. 50, pp. 1294-1298.

Moore, I., Burch, G. 1986b. Modeling erosion and deposition: topographic effects. Trans. of ASAE, Vol. 29, No. 6, pp 1624-1630, 1640.

Moore, I., Wilson, J.P. 1992. Length slope factor for the Revised Universal Soil Loss Equation: simplified method of solution. J. Soil Wat. Consrv., Vol. 47, No. 5, pp. 423-428.

Naik, G.M., Rao, E.P., Eldho T.I. 2009. Finite Element Method and GIS Based Distributed Model for Soil Erosion and Sediment Yield in a Watershed. $J$. Water Resources Management, Vol. 23, pp. 553-579.

Nash, J.E., Sutcliffe, J.V., 1970. River flow forecasting through conceptual models. Part I. A discussion of principles. $J$. Hydrol., Vol. 10, pp. 282-290.

NBSS and LUP. 2004. Soils of Uttar Pradesh for Optimizing Land Use: Executive Summary. National Bureau of Soil Survey and Land Use Planning: ICAR, Publication No., 68, Nagpur, India.

Nearing, M.A., Foster, G.R., Lane, L.J., Finkner, S.C. 1989. A process-based soil erosion model for USDA-water erosion prediction project technology. Transactions of the ASAE, Vol. 32, No. 5, pp. 1587- 1593.

Prosser, I.P., Rustomji, P., Young, B., Moran, C., Hughes, A., 2001. Constructing river basin sediment budgets for the National Land and Water Resources Audit. CSIRO Land and Water Technical Report 15/01, pp. 34, Canberra.

Ram Babu, Dhyani, B. L., Kumar, N., 2004. Assessment of erodibility status and refined Iso- Erodent Map of India. Indian J. Soil Conserv., Vol. 32, No. 2, pp. 171-177.
Raymo, M.E., Ruddiman, W.F., 1992. Tectonic forcing of late Cenozoic climate. Nature (London), Vol. 359, pp: 117-122.

Risse L.M., Nearing, M.A., Nicks, A.D., and Laflen, J.M., 1993. Error measurement in Universal Soil Loss Equation. Soil Sci. Society of America J., Vol. 57, pp. 825-833.

Singh, G., Babu, R., Narain, P., Bhusan, L.S., Abrol, I.P., 1992. Soil erosion rates in India. J. Soil and water Conservation, Vol. 47, pp. 97-99.

Singh, K.D. 2006. Participatory watershed management - a key to sustainable agriculture. J. Indian Soc. Soil Sci., Vol. 54, pp. 443-451.

Stoddart, D.R. 1969. World erosion and sedimentation in water. In: Chorley, R.J., (Ed.), Water, Earth, and Man, Methuen, London, pp. 43-64.

Takken, I., Beuselinck, B., Nachtergaele, J., Govers, G., Poesen, J., Degraer, G., 1999. Spatial evaluation of a physicallybased distributed erosion model (LISEM). Catena, Vol. 37, pp. 431-447.

United Nation Environmental Program, 1991. Status of Desertification and Implementation of the UN Plan of Action to Combat Desertification. UNEP, Nairobi, Kenya.

Van Rompaey, A., Bazzoffi, P., Jones, R.J.A., Montanarella, L., 2005. Modelling sediment yields in Italian catchments. Geomorphol., Vol. 65, pp. 157-169.

Van Rompaey, A., Verstraeten, G., Van Oost, K., Govers, G., Poesen, J., 2001. Modeling mean annual sediment yield using a distributed approach. Earth Surface Processes and Landforms, Vol. 26, No. 11, pp. 1221-1236.

Verstraeten, G., Poesen, J., 2001. Factors controlling sediment yields from small intensively cultivated catchments in a temperate humid climate. Geomorphol., Vol. 40, pp. 123-144. 
Verstraeten, G., Prosser, I.P., Fogarty, P. 2007. Predicting the spatial patterns of hillslope sediment delivery to river channels in the Murrumbidgee catchment, Australia. J. Hydrol., Vol. 334, pp. 440-454.

Wicks, J.M., Bathurst, J.C., 1996. SHESED: a physically based, distributed erosion and sediment yield component for the SHE hydrological modeling system. $J$. Hydrol., Vol. 175, pp. 213-238.

Williams, J.R., Dyke, P.T., Jones, C.A. 1983. EPIC: a model for assessing the effects of erosion on soil productivity. In Analysis of Ecological Systems: Stateof-the-Art in Ecological Modeling. Eds. W.K. Laurenroth et al., Elsevier, Amsterdam, pp. 553-572.

Wischmeier, W.H., Smith, D.D. 1978. Predicting rainfall erosion losses.
Agricultural Handbook No. 537, US Dept of Agriculture, Science and Education Administration.

Wu, S., Li, J., Huang, G. 2005. An evaluation of grid size uncertainty in empirical soil loss modelling with digital elevation models. Environ. Modeling and Assessment, Vol. 10, pp: 33-42.

Wu, T.H., Hall, J.A., Bonta, J.V. 1993. Evaluation of runoff and erosion models. J. Irrigation and Drainage Engineering, ASCE 119, pp. 364-382.

Young, R.A., Onstad, C.A., Bosch, D.D., Anderson, W.P., 1989. AGNPS: a nonpoint source pollution model for evaluating agricultural watersheds. $J$. Soil and Water Conservation, pp. 168173.

\section{How to cite this article:}

Rawat, S.S., M.K. Jain, K.S. Rawat, B. Nikam and Mishra, S.K. 2017. Vulnerability Assessment of Soil Erosion/Deposition in a Himalayan Watershed using a Remote Sensing and GIS Based Sediment Yield Model. Int.J.Curr.Microbiol.App.Sci. 6(3): 40-56. doi: https://doi.org/10.20546/ijcmas.2017.603.004 